Academic presenteeism and violence against women in schools of business and engineering in Peruvian universities

Raquel Chafloque-Céspedes, Arístides Vara-Horna, Zaida Asencios-Gonzales, Dennis López-Odar, Aldo Alvarez-Risco,

Liliana Quipuzco-Chicata, Christin Schulze and Marté Sánchez-Villagomez 
Raquel Chafloque-Céspedes, Arístides Vara-Horna, Zaida Asencios-Gonzales, Dennis López-Odar, Aldo Alvarez-Risco, Liliana Quipuzco-Chicata, Christin Schulze and Marté Sánchez-Villagomez.

\section{Academic presenteeism and violence against women in schools of business and engineering in Peruvian universities}

Abstract: The aim of the current study was to demonstrate the relationship between violence against women (VAW) in intimate partner relationships and academic presenteeism of students enrolled in business and engineering programs, at Peruvian universities. This study adopted an exploratory crosssectional survey design through a survey of 2640 university students from the business and engineering schools of 34 Peruvian universities. It was found that $96.5 \%$ of the respondents reported academic presenteeism and $32.0 \%$ are survivors of $V A W$. Partial least squares regression found that $V A W$ generates 8.47 days lost due to academic presenteeism, which at the same time generates 15.12 critical incidents with professors and colleagues, during the academic year. Finally, it was demonstrated that $V A W$ is a determining factor that explains $7.2 \%$ of university students' academic presenteeism. This study is among the very few that empirically seek to explore the actual time that students use in a day at university. Thus, it measured actual academic productive hours of university students in Peru.

Palabras clave: academic presenteeism; violence against women; intimate partner relationships; universities.

JEL Classification: $A 2, I 21, I 23$.

\section{Presentismo académico y violencia contra las mujeres en escuelas de negocios e ingeniería en universidades peruanas}

Resumen: El objetivo del presente estudio es demostrar la relación entre la violencia contra las mujeres (VCM) en las relaciones de pareja intima y el presentismo académico de los estudiantes matriculados en programas de negocios e ingeniería en universidades peruanas. Este estudio adoptó un diseño de encuesta transversal exploratoria a través de una encuesta a 2640 estudiantes universitarios de las escuelas de negocios e ingeniería de 34 universidades peruanas. Se encontró que el 96,5\% de los encuestados reportaron presentismo académico y el 32\% son sobrevivientes de VCM. La regresión de mínimos cuadrados parciales mostró que la VCM genera 8,47 días perdidos debido al presentismo académico, el cual, al mismo tiempo, genera 15,12 incidentes críticos con profesores y colegas durante el año académico. Finalmente, se demostró que la VCM es un factor determinante que explica el 7,2\% del presentismo académico de los estudiantes universitarios. Este estudio se encuentra entre los pocos que empíricamente buscan explorar el tiempo real que los estudiantes usan en un día en la universidad, por lo que midió las horas productivas académicas reales de estudiantes universitarios en Perú.

Palabras clave: presentismo académico; violencia contra la mujer; relaciones de pareja; universidades.

https://doi.org/10.17533/udea.le.n93a340726

\section{(cC) BY-NC-SA}

Este artículo y sus anexos se distribuyen por la revista Lecturas de Economía bajo los términos de la Licencia Creative Commons Atribución-NoComercial-CompartirIgual 4.0. https://creativecommons.org/licenses/by-nc-sa/4.0/ 


\section{Assiduité scolaire et violence contre les femmes dans les écoles de commerce et d'ingénieurs dans les universités péruviennes}

Résumé: L'objectif de cette étude est démontrer le rapport entre la violence contre les femmes (VCM) en ce qui concerne les relations avec leurs partenaires intimes et l'assiduité scolaire des élèves inscrits à des programmes d'affaires et de l'ingénierie, dans les universités péruviennes. Cette étude a adopté un plan d'enquête transversale exploratoire auprès de 2640 étudiants des écoles de commerce et d'ingénieurs dans 34 universités péruviennes. On a constaté que 96,5\% des étudiants enquêtés ont déclaré avoir assiduité, tandis que le 32,0\% sont des survivants de la VCM. La régression par des moindres carrés partiels montre que la VCM provoque 8,47 jours scolaires perdus à l'université, ceux qu'en même temps entraîne 15,12 disputes avec les enseignants et les collègues étudiants, au cours de l'année scolaire. Enfin, il a été démontré que la VCM explique un 7,2\% de l'assiduité des étudiants universitaires. Cette étude est parmi les très rares recherches qui explorent l'emploi du temps des élèves dans une même journée. Nous avons donc la quantité d'heures productives académiques des étudiants universitaires au Pérou.

Mots clés: assiduité scolaire; violence contre les femmes; relations avec les partenaires intimes; universités.

Cómo citar / How to cite this item:

Chafloque-Céspedes, R., Vara-Horna, A., Asencios-Gonzales, Z., López-Odar, D., Alvarez-Risco, A., Quipuzco-Chicata, L., Schulze, C. \& Sánchez-Villagomez, M. (2020). Academic presenteeism and violence against women in schools of business and engineering in Peruvian universities. Lecturas de Economía, 93, 127-153.

https://doi.org/10.17533/udea.le.n93a340726 


\title{
Academic presenteeism and violence against women in schools of business and engineering in Peruvian universities
}

\author{
Raquel Chafloque-Céspedes $\mathbb{1}^{\mathrm{a}}$, Arístides Vara-Horna $\mathbb{1}^{\mathrm{b}}$, Zaida \\ Asencios-Gonzales $\mathbb{( 1 )}^{c}$, Dennis López-Odar $\mathbb{1}^{\mathrm{d}}$, Aldo Alvarez-Risco ${ }^{\mathrm{e}}{ }^{\mathrm{e}}$, \\ Liliana Quipuzco-Chicata $\mathbb{\circledR}^{\mathrm{f}}$, Christin Schulze $\mathbb{C}^{\mathrm{g}}$ and Marté \\ Sánchez-Villagomez $\mathbb{Q}^{\mathrm{h}}$
}

-Introduction. -I. Literature review. -II. Method. -III. Results. -Conclusion. -References.

Original manuscripts received on 8 December 2019; final version accepted on 28 February 2020

a Raquel Chafloque-Céspedes: investigadora, Facultad de Ciencias Administrativas y Recursos Humanos, Universidad de San Martin de Porres, Perú. Dirección electrónica: rchafloquec@usmp.pe https://orcid.org/0000-0003-0314-5603

b Arístides Vara-Horna: investigador, Facultad de Ciencias Administrativas y Recursos Humanos, Universidad de San Martin de Porres, Perú. Dirección electrónica: avarah@usmp.pe https://orcid.org/0000-0002-3107-1157

c Zaida Asencios-Gonzales: investigadora, Facultad de Ciencias Administrativas y Recursos Humanos, Universidad de San Martin de Porres, Perú. Dirección electrónica: zasenciosg@usmp.pe http://orcid.org/0000-0003-0254-8208

d Dennis López-Odar: investigador, Facultad de Ciencias Administrativas y Recursos Humanos, Universidad de San Martin de Porres, Perú. Dirección electrónica: dlopezo@usmp.pe https://orcid.org/0000-0001-7622-7066

e Aldo Álvarez-Risco: investigador, Facultad de Ciencias Administrativas y Recursos Humanos, Universidad de San Martin de Porres, Perú. Dirección electrónica: aalvarezr@usmp.pe https:// orcid.org/0000-0003-0786-6555

f Liliana Quipuzco-Chicata: investigadora, Facultad de Ciencias Administrativas y Recursos Humanos, Universidad de San Martin de Porres, Perú. Dirección electrónica: lquipuzcoc@usmp.pe https://orcid.org/0000-0002-5200-069X

g Christin Schulze: investigadora, Facultad de Ciencias Administrativas y Recursos Humanos, Universidad de San Martin de Porres, Perú. Dirección electrónica: christin.schulzeuwera@gmail.com https://orcid.org/0000-0001-6586-1897

h Marté Sánchez-Villagomez: investigador, Facultad de Ciencias Administrativas y Recursos Humanos, Universidad de San Martin de Porres, Perú. Dirección electrónica: msanchezv1@usmp.pe https:/ /orcid.org/0000-0002-0643-4227 
Chafloque-Céspedes et al.: Academic presenteeism and violence against women in schools...

\section{Introduction}

Presenteeism is a concept applied to the business sector, referred to a context in which employees attend their workplaces, but perform their duties without making the most of their potential for reasons linked to health problems or personal life incidents (Ferritto, 2013; Merrill et al., 2012; Vänni et al., 2017; Wang et al., 2010). This concept has been extended to the academic environment, where it is pointed out that there is low academic performance among students as a result of health problems (Deroma et al., 2009; Matsushita et al., 2011; Mikami et al., 2013). However, this concept can be extended to the academic environment indicating a low academic performance due to deconcentration, inattention, or other factors.

The presenteeism research carried out in the academic environment, until now, have been associated to diseases or health problems in the undergraduate students; for example, Deroma et al. (2009) investigated the decrease of academic performance related to symptoms of depression, where it was found that depression and academic performance in university students have a negative relationship. Along the same lines, Matsushita et al. (2011) demonstrated the effect of presenteeism in academic performance and indicated university students' mental and physical diseases as main factors. They found that women's presenteeism, due to depression and emotional disorders, is $2.9 \%$ higher than men's. The same tendency occurs when the presenteeism is evaluated for migraines and headaches (women 13.6\% vs. men $6.9 \%$ ). Similar results were observed when presenteeism caused by back pain, neck pain or stomach pains is evaluated. The differences were between 8 to $15 \%$ approximately. This research sought to demonstrate the relationship between violence against women (VAW) in intimate partner relationships and academic presenteeism of university students using an exploratory crosssectional survey of 2640 participants. The impact of VAW in the number of days lost by academic presenteeism and number of critical incidents with colleagues and professors during the academic year is mainly measured. Measuring academic presenteeism in students due to VAW allowed them to demonstrate the important impact in academic performance and prioritize the creation of active VAW prevention programs in universities. 


\section{Literature review}

Considering the studies carried out in companies and universities, for the purposes of this research, academic presenteeism is defined as the situation when the student is present in class or in the places where the teaching-learning process takes place, but for aspects associated with life conditions, violence experiences, and other factors cannot meet the academic requirements to fulfill their potential. Therefore, does not develop skills, abilities and capacities required by the professional career (Ferritto, 2016; Hemps, 2004; Johns, 2011). Adams et al. (2013) explored the relation between financial harm and VAW in adolescence. A sample of 498 women found that those who had been victimized by a partner during adolescence obtained less education compared with non-victimized women. Likewise, Yoshida and Miki (2018) found different factors linked to the presenteeism in 2006 nurses working at 10 hospitals. Chafloque et al. (2018) have described firstly in Peru the presenteeism and its impact in the academic performances of university students; additionally, it was found the association between leadership quality and the development of presentism in health professions' education and research (Galliker et al., 2020).

VAW in intimate partner relationships is present in the lives of university students, who are victims in the falling in love stage, courtship or other types of relationships (Rennison \& Addington, 2014). There are studies that consider only the presence of physical violence (threw something that could hurt her, held strongly, slapped, used a gun or knife against her partner, hit with objects, choked, burned and others) and sexual violence (forced to have sex without condom, insisted on having sex without consent, insisted on having oral or anal sex, and other manifestations) in the undergraduate students (Chan et al., 2008). Likewise, other investigations have found evidence of a single manifestation of violence within the university environment (Jordan et al., 2014; Phipps \& Smith, 2012). There are also researches that have included analyzes about the prevalence in universities of psychological and verbal violence (Vázquez et al., 2010).

Chan et al. (2008) conducted their research in a sample of undergraduate students from 22 countries (Asia and the Middle East, New Zealand and 
Chafloque-Céspedes et al.: Academic presenteeism and violence against women in schools...

Australia, Europe, Latin America and North America). In the mentioned study was found that the prevalence of physical violence in female students from the 22 countries ranged from 12.1 to $41.1 \%$, while sexual violence ranged from 9.2 to $42 \%$. Other VAW evidence that was studied in the academic environment is the research of Jordan et al. (2014), were a sample of 750 undergraduate students showed that the prevalence of some form of sexual violence in the study period ranged between 19.6 and $24.2 \%$, while $4.1 \%$ (first semester students) and 3.1\% (students in the second semester) reported having suffered a rape. Vázquez et al. (2010) showed that VAW in 159 Spanish students was manifested in psychological violence, physical violence and sexual violence, which had been perpetrated by their partners, being psychological violence the most incident one $(65.2 \%)$, followed by physical violence $(28.8 \%)$ and some students presented two types of violence at the same time, such as physical and psychological $(1.5 \%)$ or physical and sexual (4.5\%). Furthermore, Herrera and Arenas (2010) conducted their study in a sample of 73 female students, where it was reported that $34.2 \%$ had suffered verbal and psychological violence, $20.5 \%$ suffered physical violence, and $2.7 \%$ of the students suffered violence sexual.

There have been studies carried out to investigate academic presenteeism. One of those is Mikami et al. (2013), where it was related the academic presenteeism with the state of health and the sense of coherence. Another study related academic presentism with academic performance, finding that students with emotional problems have the highest prevalence of presenteeism (Matsushita et al., 2011). In the same line, Ferrito (2016) explained that presenteeism is a factor associated with academic performance.

There are several researches that have been developed in the business context and have concluded that VAW is a determinant of labor presentism. For example, in Peru, in public schools in the Callao region, teachers affected by VAW lost 8.9 working days due to presenteeism (Vara-Horna et al., 2017). In Bolivia, as a result of the VAW, the attacked workers lost 18.9 business days a year due to presentism (Vara-Horna, 2015). In Paraguay, VAW is causing a yearly loss of productivity due to presenteeism of 25.6 days per worker attacked (GIZ, 2015). Similarly, researches have been carried out in countries from the Middle East and Africa. In Ghana and South Sudan, as a result of 
VAW, assaulted workers yearly lost 5 and 3 days of work due to presenteeism, respectively (Asante et al., 2019; University of Limerick \& NUI Galway, 2019; Elmusharaf et al., 2019). Also, in Pakistan, workers affected by VAW lost an average of 2 days of work per year (Social Policy and Development Centre -SPDC— et al., 2019).

From the above, VAW causes pernicious effects on the labor productivity of companies. This is measured in terms of presenteeism, as Swanberg et al. (2006) affirm. Indeed, a knowledge gap about the relationship of VAW and academic presentism in a sample of university students. In fact, researches that associate or relate VAW as a determining factor of academic presenteeism are scarce. Nevertheless, there researches' evidence that relates the types of VAW and the factors of presenteeism, and how these affect academic performance.

Umana et al. (2014), related the prevalence of VAW with psychological, social and academic factors. In their analysis, it was found that female university students who are survivors of violence had a significant decrease in their concentration $(71 \%)$ and the risk of dropping out the academic semester increased by 3.3\%. Likewise, Jordan et al. (2014) determined that university students who were victims of sexual violence were three times more likely to obtain a lower grade point average compared to non-victims. The researchers indicated that the sexual violence that students experience impacts their cognitive processes, presenting deficits to concentrate, plan their activities and remember the lessons or tasks. Finally, Edwards et al. (2015) analyzed the association of psychological variables with intimate partner relationships in 139 students. This study reveals a positive relationship between VAW and psychological symptoms such as stress, anxiety, depression and others.

The aim of this paper was to examine, in a national representative sample of university students, the relation of VAW and academic presenteeism. This, through the use of structural equations of variance and counterfactual scenarios, demonstrated that VAW is a determining factor of academic presenteeism. 
Chafloque-Céspedes et al.: Academic presenteeism and violence against women in schools...

\section{Method}

\section{A. Participants}

The sample considered only female students from business and engineering schools. These schools were chosen because the students who have chosen these schools will hold managerial positions in the future. However, in Peru the schools mentioned do not have a gender focus in their curricular plan. Indeed, if the participants construct unequal patterns and of violence, in the future it will affect their role as agents in the management of companies.

The research considered 2640 female students, who are currently in an intimate partner relationship, aged 18 to 25 years with a mean age of 20.50 years $(\mathrm{SD}=1792)$, enrolled in business and engineering schools from 34 universities. The 21 regions of Peru were distributed in 8 zones (northern coast, central coast, southern coast, northern highlands, central highlands, southern highlands, northern and southern Amazonia). Table 1 describes the demographic, academic and professional profile of the surveyed students.

\section{B. Instruments}

The study used a structured self-report questionnaire. Questions were included to gather demographic, academic and professional information, academic presenteeism, psychological, verbal, physical, economic and sexual violence.

The instrument had 30 items, of which 14 described demographic and academic characteristics of the students, 9 items measured presenteeism and 7 items measured violence against these female students.

- Demographic information: Inquires the personal information of the respondent. The items considered were: age, number of daughters/sons, if they have a partner, type of relationship (dating, engaged, married or living together, separated or divorced, others) and duration of relationship. 
Table 1. Demographic, academic and work profile of simple (percentages)

\begin{tabular}{lccc}
\hline \multicolumn{2}{l}{ Characteristic } \\
\hline Knowledge area & \multicolumn{3}{l}{ Zones } \\
Business & 80.5 & Coast - north & 17.1 \\
Engineering & 19.1 & Coast - center & 33.2 \\
Occupation & & Coast - south & 5.5 \\
Only study & 62.0 & Mountains - north & 2.8 \\
Study and work & 38.0 & Mountains - center & 4.6 \\
Children & 7.2 & Mountains - south & 27.5 \\
Yes & 92.8 & Jungle - north & 5.4 \\
No & & Jungle - south & 3.9 \\
Type of relationship & 79.6 & Type of university & \\
In love & 11.8 & Public & 64.2 \\
Boyfriends & 6.9 & Private & 35.8 \\
Married or cohabiting & 0.3 &
\end{tabular}

Source: own elaboration based on 2640 surveys to female students which have o had relationship.

- Academic and professional information: Gathers academic and professional information of the respondent. The items included are year of admission to the university, current semester, quantity of failed courses, repeated cycles, and occupation (if she only studies, if she studies and works).

- Presentism: This scale is based on the work distraction items of Stewart et al. (2003) and the Work Limitations Questionnaire (WLQ) by Lerner et al. (2001). The scale identified the diminished academic performance during the last month. The scale of presenteeism had four dimensions that represent four stages of consecutive and sequential effects. In the first stage the presenteeism is reflected in the distraction and exhaustion 
Chafloque-Céspedes et al.: Academic presenteeism and violence against women in schools...

of the student; in the second stage it is reflected in the perceived decrease of academic productivity; in the third stage it is observed in the deterioration of social cohesion with colleagues and professors; and in the fourth stage it is reflected in the intention to drop out.

In the four dimensions, each item had alternative ordinal responses with interval interpretation values: never (0), 1 day (1), between 2 and 5 days (4), between 6 and 10 days (8), almost every day (15).

To calculate the prevalence of academic presenteeism, the weights and formulas described in Table 2 were used. The items P1, P2, P3 and P4 indicate the decrease in academic productivity, $25 \%$ of the productivity loss of the day involved is assumed. Items P5, P6, P7 and P8 serve as indicators to find the number of productivity incidents, where $100 \%$ was assumed for each occurred incident. To calculate the presenteeism by distraction and monthly exhaustion (in days) the weighted data was added, and multiplied by eight (number of months of the academic year in Peruvian universities) to estimate the annual presenteeism (in days). To calculate the presenteeism for incidents of monthly productivity (number of incidents) the already weighted data was added, then, to calculate the academic year it was multiplied by eight (number of months of the academic year).

- VAW in intimate partner relationships: This scale is based on the Conflict Tactics Scales 2 (Straus et al., 1996). For the type of sample (students), the 7 most representative items of the psychological, economic, physical, sexual and physical damage, executed by the partner or ex-partner, subscales were considered. Each item was weighted according to the intensity level of the attack; and had alternatives of ordinal responses with interval interpretation: never (0), happened before, not anymore (0), once or twice (4), between 3 to 5 times (4), between 6 and 10 times (8), between 11 to 20 times (15), more than 20 times (25). The scale determined the presence of VAW by her partner in the last year and the prevalence of this violence throughout her life. 
Table 2. Items, weigh and formulas about presenteeism in students

\begin{tabular}{|c|c|c|c|c|}
\hline Stage & & Items (Last four weeks...) & Weight & Algorithms \\
\hline \multirow{4}{*}{ Distraction } & P1 & $\begin{array}{l}\text { You have had difficulty concen- } \\
\text { trating or been distracted in } \\
\text { class or while studying. }\end{array}$ & 0.25 & \multirow{4}{*}{$\begin{array}{l}\text { Presenteeism: } \\
\text { Distraction and } \\
\text { monthly exhaustion } \\
(\text { days })=\sum(\mathrm{P} 1 * 0.25 \text {, } \\
\mathrm{P} 2^{*} 0.25, \mathrm{P} 3^{*} 0.25, \\
\left.\mathrm{P} 4^{*} 0.25\right)\end{array}$} \\
\hline & P4 & $\begin{array}{l}\text { You had other people's personal } \\
\text { concerns to classes. }\end{array}$ & 0.25 & \\
\hline & P2 & You studied slower than usual. & 0.25 & \\
\hline & P3 & $\begin{array}{l}\text { You were tired, worn out, or } \\
\text { exhausted while in class or } \\
\text { studying. }\end{array}$ & 0.25 & \\
\hline \multirow[t]{2}{*}{$\begin{array}{l}\text { Stage 2: Decreased } \\
\text { productivity }\end{array}$} & P5 & $\begin{array}{l}\text { You made mistakes in their } \\
\text { presentation of papers or exams } \\
\text { because you were worried or } \\
\text { anything affect you. }\end{array}$ & 1 & \multirow{5}{*}{$\begin{array}{l}\text { Incidents of } \\
\text { monthly } \\
\text { productivity } \\
\text { (incidents) }=\sum \\
(\mathrm{P} 5, \mathrm{P} 6, \mathrm{P} 7, \mathrm{P} 8)\end{array}$} \\
\hline & P8 & $\begin{array}{l}\text { You have had an academic } \\
\text { performance well below their } \\
\text { capabilities. }\end{array}$ & 1 & \\
\hline \multirow[t]{2}{*}{$\begin{array}{l}\text { Stage 3: } \\
\text { Deterioration of } \\
\text { social cohesion }\end{array}$} & P6 & $\begin{array}{l}\text { You received reprimands or } \\
\text { warnings of their professors for } \\
\text { their performance. }\end{array}$ & 1 & \\
\hline & P7 & $\begin{array}{l}\text { You have struggled or discus- } \\
\text { sions with peers / as for not } \\
\text { fulfilling assignments. }\end{array}$ & 1 & \\
\hline $\begin{array}{l}\text { Stage 4: Intention } \\
\text { of desertion }\end{array}$ & P9 & $\begin{array}{l}\text { You had desire to abandon their } \\
\text { studies. }\end{array}$ & 1 & \\
\hline
\end{tabular}

Source: own elaboration based on 2640 surveys to female students which have o had relationship.

\section{Procedure}

The questionnaire was administered and assisted in person by professors and qualified professionals. The average time was 25 minutes. Students were informed of the nature, objectives and benefits of the study, guaranteeing their confidentiality and anonymity. Also, all the questions and doubts raised 
Chafloque-Céspedes et al.: Academic presenteeism and violence against women in schools...

were answered. The participation in the study was voluntary, without any kind of academic, economic or other compensation. The students gave verbal consent before the data collection, in addition to also asking consent questions at the end of the questionnaire. The protocol was approved by the review team of the Universidad de San Martín de Porres.

\section{Data analysis}

Tabulation and data analysis was done using the statistical programs SPSS version 23, Smart PLS version 3.2 and Stata version 14. Contingency tables, means and percentages were used in order to obtain the demographic, academic characteristics and prevalence estimates of the studied variables. For reliability analysis of the internal consistency of each scale, the reliability coefficient of Cronbach's Alpha was used. The presenteeism scale $(\alpha=0.833)$ and the VAW scale $(\alpha=0.754)$ obtained Alpha values above the expected minimum (0.706).

Regarding the analysis of construct validity, Factorial Analysis (FA) was used with the Principal Axis Method of Factor Extraction and Promax rotation. The 16 items analyzed ( 9 items of the presenteeism scale and 7 items of the VAW scale) provided a 2 -axis factorial solution, with a total variance that can be explained by $67.9 \%$ of the original data. The factorial weights of the items of the VAW scale met the requirements to be validated due that the factorial weights exceeded 0.706 , and the communalities $50 \%$. The items of the presenteeism scale obtained factorial weights between 0.604 and 0.820 , though three of nine items did not meet the established requirements to be validated.

Structural equation modelling of partial least squares (PLS-SEM) was used to give a greater support to the scales validation. Table 3 shows that all the factorial weights of the items of the two scales are higher than the expected minimum (0.706), showing high levels of composite reliability (between 0.776 and 0.891 ) and an average extracted variance by scale between 0.615 and 0.804 . 
Table 3. Validity of items of Presenteeism and VAW through Structural Equations of Variance using PLS

\begin{tabular}{|c|c|c|c|}
\hline Items & $\begin{array}{l}\text { Factor } \\
\text { Weight }\end{array}$ & $\begin{array}{l}\text { Composite } \\
\text { reliability }\end{array}$ & $\begin{array}{l}\text { Variance } \\
\text { extracted }\end{array}$ \\
\hline I have difficulty of concentration or I have been distracted. & 0.819 & 0.864 & 0.615 \\
\hline I had personal concerns unrelated to study. & 0.753 & & \\
\hline I have studied slower than usual. & 0.805 & & \\
\hline I was exhausted while I was studying or in class. & 0.756 & & \\
\hline I had mistaken in my tests or presentation of tasks. & 0.851 & 0.832 & 0.713 \\
\hline I have decreased my academic performance. & 0.837 & & \\
\hline I had reprimands or warnings of my professors. & 0.846 & 0.802 & 0.670 \\
\hline I have had discussions with my colleagues. & 0.790 & & \\
\hline $\begin{array}{l}\text { My partner humbled you and said things that made you feel } \\
\text { less or feel bad. }\end{array}$ & 0.895 & 0.882 & 0.789 \\
\hline My partner took hold of my income or my salary. & 0.842 & 0.800 & 0.667 \\
\hline My partner threatened me, insulted or verbally attacked. & 0.901 & 0.891 & 0.804 \\
\hline My partner hit me, slap, kick, bit or strongly held my arm. & 0.906 & 0.884 & 0.792 \\
\hline $\begin{array}{l}\text { My partner attacked me with objects, sticks, sharp stabbing } \\
\text { weapons or firearms. }\end{array}$ & 0.774 & 0.865 & 0.617 \\
\hline My partner forced me to have sex without my consent. & 0.818 & 0.776 & 0.635 \\
\hline $\begin{array}{l}\text { My partner caused me serious physical injuries (bruises, } \\
\text { sprains, injuries). }\end{array}$ & 0.828 & 0.866 & 0.764 \\
\hline
\end{tabular}

Source: own elaboration based on 2640 surveys to female students which have o had relationship.

Using the structural equations of partial least squares it was found that Presenteeism has three sequentially linked dimensions. The distraction and exhaustion explains the $42.3 \%$ of the diminished performance, and the latter explains $20.2 \%$ of the decrease of the social cohesion by the claims and discussions with colleagues and professors. The impact of VAW was calculated by creating counterfactual scenarios. Two comparison groups have been established: case (women who have experienced VAW) and 
Chafloque-Céspedes et al.: Academic presenteeism and violence against women in schools...

control (women have not experienced VAW). In both groups, the averages of presenteeism were compared in days and incidents. The marginal difference of these averages is assumed as the impact of partner violence excluding other impacts, as long as the differences are significant using the null hypothesis test with a probability of less than $1 \%$.

\section{Results}

\section{A. Descriptive Statistics}

$96.5 \%$ of female university students manifested that they were distracted or exhausted in the last month during their classes, $82.2 \%$ manifested that in the last month they felt that their academic performance had decreased, $51.2 \%$ manifested that due to complaints and criticism for their low performance their social cohesion with colleagues and professors decreased, while $32.3 \%$ of the students reported intention to drop out the semester. On average, the students had 28.26 days lost (S.D. $=25.936)$ of classes and had 61.094 (S.D. = 61.09) incidents (discussions, reprimands or warnings) with their fellow students and professors in the academic year.

$47.7 \%$ of students have experienced VAW in intimate partner relationships at some point in their lives. The most prevalent aggressions were psychological violence $(42.5 \%)$, followed by verbal violence $(20.0 \%)$, mild physical violence $(13.4 \%)$, physical damage $(5.9 \%)$, sexual violence $(5.9 \%)$, economic violence $(4.5 \%)$, and serious physical violence $(2.5 \%)$. While $32.0 \%$ of students have experienced VAW in the last year, the aggressions reported were psychological violence $(25.9 \%)$, followed by verbal violence $(11.5 \%)$, mild physical violence $(8.2 \%)$, physical damages $(3.2 \%)$, sexual violence $(3.1 \%)$, economic violence $(2.7 \%)$ and serious physical violence $(1.0 \%)$. The average rate of incidents perpetrated in the last academic year was 6.57 times per year.

\section{B. VAW as a determining factor of presenteeism}

Table 4 shows the comparison of presenteeism in the groups of students who experience situations of partner violence in the last year and the group 
that has never experienced it. The prevalence of presenteeism in students who experience VAW is between 3.3 and 13.7 percentage points higher than the presenteeism of the group that does not suffer. The desire of the students to drop out their studies is superior in $13 \%$, in comparison with those that do not experience VAW.

Table 4. Prevalence of presenteeism of students according experience of VAW during the last year (percentages)

\begin{tabular}{lccc}
\hline Items & $\begin{array}{c}\text { Without } \\
\text { violence }\end{array}$ & $\begin{array}{c}\text { With } \\
\text { violence }\end{array}$ & $\begin{array}{c}\text { Chi } \\
\text { Square }\end{array}$ \\
\hline $\begin{array}{l}\text { I have difficulty of concentration or I was distracted } \\
\text { when I was studying. }\end{array}$ & 81.9 & 89.5 & $87.494^{*}$ \\
I study slower than usual. & 76.0 & 86.2 & $71.476^{*}$ \\
I was exhausted while I was studying or in class. & 89.1 & 92.4 & $48.981^{*}$ \\
I had personal concerns unrelated to study. & 72.1 & 85.8 & $128.179^{*}$ \\
I had errors in my tests or presentation of tasks because & 68.1 & 75.1 & $41.285^{*}$ \\
I was worried or something affected me. & & & \\
I had reprimands or warnings from my professors. & 28.5 & 35.0 & $25.961^{* *}$ \\
I had difficulties or discussions with peers for not & 34.7 & 41.5 & $16.044^{* *}$ \\
fulfilling assignments. & & & \\
I had an academic performance well below my abilities. & 57.2 & 67.5 & $58.582^{*}$ \\
I had desire to leave my studies. & 27.9 & 40.9 & $65.947^{*}$ \\
\hline
\end{tabular}

Note: ${ }^{*} \mathrm{P}<0.01 ;{ }^{* *} \mathrm{P}<0.05$.

Source: own elaboration based on 2640 surveys to female students which have o had relationship.

\section{The causal impact using SEM-PLS}

To analyze the existing relationship of VAW in intimate partner relationships and the variable presenteeism, structural equations of variance were used, finding that VAW has a direct impact on presenteeism, explaining it in a $7.2 \%$ either causing distraction, decrease in productivity or fostering the social cohesion of female university students. 
Chafloque-Céspedes et al.: Academic presenteeism and violence against women in schools...

In Table 5 , it is observed that relations are stable and similar to the population parameters, since they have small standard errors. It is also observed that the size of the effect is small; however, it is significant because the confidence interval of $\mathrm{F}^{2}$ value ranges between 0.006 and 0.025 .

Table 5. Relation between dimensions: VAW during the last year and Presenteeism

\begin{tabular}{lcccc}
\hline Analysis SEM - PLS (Beta values) & $\begin{array}{c}\text { Original } \\
\text { simple / F (O) }\end{array}$ & $\begin{array}{c}\text { Sample mean } \\
\text { / F (M) }\end{array}$ & $\begin{array}{c}\text { Standard } \\
\text { error } \\
\text { (STERR) }\end{array}$ & $\begin{array}{c}\text { T Statistic } \\
\text { (O/STERR) }\end{array}$ \\
\hline Significance of the path coefficients & 0.247 & 0.251 & 0.020 & 12.304 \\
Effect size coefficients & 0.065 & 0.068 & 0.012 & $5.602^{*}$ \\
\hline
\end{tabular}

Note: simulation by bootstrapping. Resampling (5000 times), $\mathrm{p}<0.01$; Bootstrapping is a nonparametric procedure applied to test whether the path coefficients (beta) are significant, by estimating standard errors for estimates. All values are significant. ${ }^{*} \mathrm{P}<0.01$.

Source: own elaboration based on 2640 surveys to female students which have o had relationship.

\section{Counterfactual scenario}

There were significant differences in the days and incidents of presenteeism occurred in the academic year, when the groups are compared according to the experience of VAW. The group of students who experienced VAW had a higher number of days with presenteeism $(36.34$, S.D. $=26.834)$ compared to the group of students who have never experienced VAW (28.32, S.D. $=24.277)$.

Regarding the incidents caused by presenteeism, the group of students who experienced VAW at present had more incidents caused by presenteeism compared to the group that never experienced VAW (72.08, S.D. $=81.110 \mathrm{vs}$ 54.96, S.D. $=71.643$ ).

To support these averages, the Propensity Score Matching (PSM) technique was used in order to match the comparisons and ensure that groups are quasi-equivalent. This is done because the comparison groups were not equivalent. Propensity scores have been calculated taking into consideration 
the demographic variables that show significant differences in the comparison groups (see Table 6).

Table 6. Demographic and educational differences in students according experience of VAW during the last year (percentages)

\begin{tabular}{|c|c|c|c|c|}
\hline & Items & $\begin{array}{l}\text { Without Violence } \\
\qquad(\mathrm{N}=1715)\end{array}$ & $\begin{array}{l}\text { With Violence } \\
\qquad(\mathrm{N}=1787)\end{array}$ & Chi Square \\
\hline \multirow{2}{*}{ Schools } & Business & 80.9 & 81.0 & \multirow{2}{*}{0.509} \\
\hline & Engineering & 19.1 & 19.0 & \\
\hline \multirow{2}{*}{ Occupation } & Only study & 65.6 & 60.6 & \multirow{2}{*}{$10.477^{* *}$} \\
\hline & Study and work & 34.4 & 39.4 & \\
\hline \multirow{2}{*}{ Children } & Yes & 4.2 & 8.5 & \multirow{2}{*}{$26.828^{*}$} \\
\hline & No & 95.8 & 91.5 & \\
\hline \multirow{2}{*}{ Couple } & Yes & 53.3 & 61.2 & \multirow{2}{*}{$24.698^{*}$} \\
\hline & No & 46.7 & 38.8 & \\
\hline \multirow{5}{*}{ Type of relationship } & In love & 82.6 & 77.1 & \multirow{5}{*}{$18.681^{*}$} \\
\hline & Boyfriends & 11.4 & 12.3 & \\
\hline & Married or cohabiting & 4.6 & 8.8 & \\
\hline & Separated or divorced & 0.3 & 0.3 & \\
\hline & Others & 1.1 & 1.5 & \\
\hline
\end{tabular}

Note: ${ }^{*} \mathrm{P}<0.01 ;{ }^{* *} \mathrm{P}<0.05$.

Source: own elaboration based on 2640 surveys to female students which have o had relationship.

In Table 7 , it is observed that the VAW caused 8.47 days of presenteeism by distraction and exhaustion; these 8.47 days of presenteeism were similar to the result of unpaired averages (8.02 days). The number of critical incidents due to presenteeism (decreased performance and warnings or discussions with colleagues and / or professors) caused by VAW were 15.12 critical incidents in the academic year. 
Chafloque-Céspedes et al.: Academic presenteeism and violence against women in schools...

Table 7. Differences of presenteeism according to experience VAW (during the last year), through Propensity-Score Matching

\begin{tabular}{cccccccc}
\hline Scale & $\begin{array}{c}\text { Mean } \\
\text { differences } \\
\text { (unmarched) }\end{array}$ & $\begin{array}{c}\text { Differences } \\
\text { marched } \\
\text { (Coef. B) }\end{array}$ & $\begin{array}{c}\text { Standard } \\
\text { error } \\
\text { strong }\end{array}$ & z & CI 95\% \\
\hline $\begin{array}{c}\text { Presenteeism (days) } \\
\text { Presenteeism } \\
\text { (incidents) }\end{array}$ & 8.02 & 8.47 & 1.19 & $7.09^{*}$ & 6.1 & 10.8 \\
\hline
\end{tabular}

Note: number of observations Paired $=1761$. Variables used to match: faculty, occupation, have children, have a partner, relationship type. ${ }^{*}$ Significant differences $(\mathrm{p}<0.01)$.

Source: own elaboration based on 2640 surveys to female students which have o had relationship.

\section{Conclusion}

In Peru, as in many countries, VAW assessment studies have been carried out in companies and how this influences the effects of presenteeism and how these influence corporate costs, finding large economic losses, which has allowed the development of management models that help reduce VAW in companies (Logan et al., 2012; Duvvury et al., 2013). However, until now, Peruvian institutions have not addressed yet how VAW has an impact on university life, in view of this current scenario where VAW has been neglected among Peruvian university students. This is where the need to carry out research that addresses the university environment arises in order to look for solutions to university education.

The present study addressed the relationship of VAW in intimate partner relationships as a determining factor of academic presenteeism in female students of Peruvian universities. This research is one of the first to address this issue, however, several researchers from the academy have proven how VAW can affect academic performance (Mengo \& Beverly, 2015; Valls et al., 2016).

The current study explained that academic presentism has four consecutive and sequential stages. These stages include distraction and exhaustion, decrease of social cohesion, decrease of academic performance, 
and finally the intention to drop out. These first two would cause days of presenteeism, while the decrease of social cohesion would cause incidents. Almost all the participants said that sometime during the academic year they were distracted or exhausted, 8 out of 10 of the participants manifested that they feel their productivity has decreased. Likewise, half of the participants stated that due to their decrease in productivity, they had problems with their professors and fellow students, while the third part indicated that they had wanted to withdraw from the study semester. These results are related to different factors and not only they can happen to female students.

Another important result of the current study was the VAW report, where 3 out of 10 participants reported that they have suffered aggressions by their partners during the last year. This result is similar to the investigation of Umana et al. (2014), where it was found that $42.3 \%$ of students from Nigerian universities suffered violence by their partners. In the current study, the reported prevalence is lower because it is reported the violence suffered during the last year. As in other researches, the most prevalent aggressions were psychological violence, verbal violence and physical violence (RubioGaray et al., 2012; Rennison \& Addington, 2014; Umana et al., 2014).

Finally, through the Propensity Score Matching, it was found that the VAW generates 8.47 days lost due to academic presenteeism caused by distraction and exhaustion. At the same time, 15.12 critical incidents with professors and colleagues are generated in the academic year. Based on the results obtained, it is found that VAW can be assumed as one of the factors that determine the academic presentism of the female students by $7.2 \%$.

One reason why academic presenteeism would be determined by VAW may be due to the fact that students suffering from VAW, after being assaulted, feel anguished, guilty, depressed or some other symptom that does not allow them to completely concentrate during the moment of class. This conclusion is consistent with the research of Edwars et al. (2015), where it is suggested that women assaulted by their partners are related to distress and psychological symptoms positively. This means that the more aggressions perpetrated by their partners, the female students feel more anguished, guilty or other psychological symptoms. Another study that supports this 
Chafloque-Céspedes et al.: Academic presenteeism and violence against women in schools...

conclusion is the one conducted by Hossain et al. (2014), were it is examined the association between depression and sexual violence. The results showed that students who were reported as diagnosed with depression had 1.56 times more probabilities than those who had never been diagnosed with depression for having experienced sexual violence.

As shown in the current study, there was a complex relationship between presenteeism and VAW in the educational field. However, in the business context, VAW is a determining factor of presenteeism and this affects the business costs. Indeed, the study by Reeves and O'Leary-Kelly (2007) reported that current victims of intimate partner violence had an average of 72 hours of more distraction annually, compared to those who were not victims. In this regard, the results of the current study showed that in the educational field VAW can also act as a determining factor of academic presenteeism.

Despite the information obtained from the current study, there were limitations that should be mentioned. In the first place, the sample was demographically homogeneous, in spite of having a national sample, it is not possible to generalize the results to the whole country since the sample is not proportional to the number of students per region. Future researches should include proportional samples from all regions of the country in order to carry out a better analysis. Secondly, the current study used a transversal design, which did not allow to analyze a temporal sequence between VAW and presenteeism. It is possible that students who experience aggression by their partner, more frequently, wish to drop out or this presentism becomes absenteeism. The current study's understanding of these complex processes would be improved by the use of longitudinal methodologies.

Although continuous research is needed in order to explore more specifically VAW as a determining factor of presenteeism, the current study provides some scopes for improving educational policies and management models in universities. First, the results suggest that due to VAW there may be distraction and exhaustion, decreased productivity, problems with professors and the intention to drop out. As well as, it is reported high prevalence of different types of VAW that students are currently suffering. Educational institutions could develop VAW prevention strategies and programs to treat 
students who are suffering VAW. Although VAW is invisibilized by students because of their age (Miller, 2017), it is necessary for universities to have these prevention programs. As authorities, professors and students become aware of how VAW affects university life, models of prevention and intervention will be promoted in the university context.

\section{References}

Adams, A. E., Greeson, M. R., Kennedy, A. C. \& Tolman, R. M. (2013). The effects of adolescent intimate partner violence on women's educational attainment and earnings. Journal of Interpersonal Violence, 28(17), 32833300 .

Asante, F., Fenny, A., Dzudzor, M., Chadha, M., Scriver, S., Ballantine, C. \& Duvvury, N. (2019). Economic and Social Costs of Violence Against Women and Girls in Ghana: Country Technical Report. Irlanda: Galway NUI.

Chafloque-Céspedes, R., Vara-Horna, A., Lopez-Odar, D., Santi-Huaranca, I., Diaz-Rosillo, A. \& Asencios-Gonzalez, Z. (2018). Ausentismo, presentismo y rendimiento académico en estudiantes de universidades peruanas. Propósitos y Representaciones, 6(1), 83-133.

Chan, K., Straus, M., Brownridge, D., Tiwari, A. \& Leung, W. (2008). Prevalence of dating partner violence and suicidal ideation among male and female University Students Worldwide. Journal of Midwifery \& Women's Health, 53(6), 529-537. http://doi.org/10.1016/j.jmwh.200 8.04.016

Deroma, V., Leach, J. \& Leverett, J. (2009). The relationship between depression and college academic performance. College Student Journal, 43(2), 325-335.

Duvvury, N., Callan, A., Carney, P. \& Raghavendra, S. (2013). Intimate partner violence: Economic costs and implications for growth and development (Women's Voice, Agency, \& Participation Research Series, No. 3). https://openknowledge.worldbank.org/bitstream/handle/10986 
Chafloque-Céspedes et al.: Academic presenteeism and violence against women in schools...

/16697/825320WP0Intim00Box379862B00PUBLIC0.pdf?sequence= 1

Edwars, K., Dardis, C., Sylaska, K. \& Gidycz C. A. (2015). Informal social reactions to college women's disclosure of intimate partner violence: Associations with psychological and relational variables. Journal of Interpersonal Violence, 30(1), 25-44. http://doi.org/10.1177/088626 0514532524

Elmusharaf, K., Scriver, S., Chadha, M., Ballantine, C., Raghavendra, S., Sabir, M., Duvvury, N., Kennedy, J., Grant-Vest, S. \& Edopu, P. (2019). Economic \& social costs of VAWG violence against women \& girls South Sudan. https:/www.whatworks.co.za/resources/reports/item/594-eco nomic-and-social-costs-of-violence-against-women-in-south-sudan-te chnical-report

Ferritto, V. (2013). Presenteeism, participation in a worksite wellness program, and employee income and education: a correlational quantitative study of workers in the New York Designated Market Area (NYDMA) (Dissertation, Capella University, UMI 3593082).

Ferritto, V. (2016). Maritime education factors and presenteeism: A comparative quantitative study. WMU Journal of Maritime Affairs, 15(2), 353-380. http://doi.org/10.1007/s13437-015-0098-9

Galliker, S., Nicoletti, C., Feer, S., Etzer-Hofer, I., Brunner, B., Grosse Holtforth, M., Melloh, M., Dratva, J. \& Elfering, A. (2020). Quality of leadership and presenteeism in health professions education and research: a test of a recovery-based process model with cognitive irritation and impaired sleep as mediators. Psychology, Health \& Medicine, 25(2), 239251.

GIZ (Deutsche Gesellschaft für Internationale Zusammenarbeit) (2015). Los costos empresariales de la violencia contra las mujeres en Paraguay. Asunción, Paraguay: AGR SA Servicios Gráficos.

Hemp, P. (2004). Presenteeism: At work - but out of it. Harvard Business Review, 82(10), 49-58. 
Herrera, J. M. \& Arena, C. A. (2010). Consumo de alcohol y violencia doméstica contra las mujeres: un estudio con estudiantes universitarias de México. RLAE, 18(559), 557-564.

Hossain, M., Memiah, P. \& Adeyinka, A. (2014). Are female college students who are diagnosed with depression at greater risk of experiencing sexual violence on college campus? Journal of Health Care for the Poor and Underserved, 25(3),1341-1359. http://doi.org/10.1353/hpu.2014.0146

Johns, G. (2011). Attendance dynamics at work: the antecedents and correlates of presenteeism, absenteeism, and productivity loss. Journal of Occupational Health Psychology, 16(4), 483-500. http://doi.org/10.1 037/a0025153

Jordan, C., Combs, J. \& Smith, G. (2014). An Exploration of Sexual Victimization and Academic Performance Among College Women. Sage Journal, 15(3), 131-200. http://doi.org/10.1177/1524838014520637

Lerner, D., Amick III, B., Rogers, W., Malspeis, S., Bungay, K. \& Cynn, D. (2001). The work limitations questionnaire. Medical Care, 39(1), 72-82.

Logan, T., Walker, R. \& Hoyt, W. (2012). The economic costs of partner violence and the cost-benefit of civil protective orders. Journal of Interpersonal Violence, 27(6), 1137-1154. http://doi.org/10.1177/08 86260511424500

Matsushita, M., Adachi, H., Arakida, M., Namura, I., Takahashi, Y., Miyata, M. \& Sugita, Y. (2011). Presenteeism in college students: Reliability and validity of the presenteeism scale for students. Quality of Life Research, 20(3), 439-446. http://doi.org/10.1007/s11136-010-9763-9

Mengo, C. \& Beverly, M. (2015). Violence victimization on a college campus. Impacts on GPA and school dropout. Journal of College Student Retention: Research, Theory \& Practice, 18(2), 234-248. http://doi.org/10.1177/15 21025115584750

Merrill, R., Aldana, S., Pope, J., Anderson, D., Coberley, C. \& Whitmer, R. (2012). Presenteeism according to healthy behaviors, physical health, 
Chafloque-Céspedes et al.: Academic presenteeism and violence against women in schools...

and work environment. Population Health Management, 15(5), 293-301. http://doi.org/10.1089/pop.2012.0003

Mikami, A., Matsushita, M., Adachi, H., Suganuma, N., Koyama, A., Ichimi, N. \& Sugita, Y. (2013). Sense of coherence, health problems, and presenteeism in japanese university students. Asian Journal of Psychiatry, 6(5), 369-372. http://doi.org/10.1016/j.ajp.2013.03.008

Miller, E. (2017). Prevention of and interventions for dating and sexual violence in adolescence. Pediatric Clinics of North America, 64(2), 423$434 \mathrm{http}: / /$ doi.org/10.1016/j.pcl.2016.11.010

Phipps, A. \& Smith, G. (2012). Violence against women students in the UK: Time to take action. Gender and Education, 24(4), 357-373. http://doi.org/10.1080/09540253.2011.628928

Reeves, C. \& O'Leary-Kelly, A. (2007). The effects and costs of intimate partner violence for work organizations. Journal of Interpersonal Violence, 22(3), 327-344. http://doi.org/10.1177/0886260506295382

Rennison, C. \& Addington, L. (2014). Violence against college women: A review to identify limitations in defining the problem and inform future research. Trauma, Violence, and Abuse, 15(3), 159-169. http://doi.org/ $10.1177 / 152483801452072$

Rubio-Garay, F., López-Gonzáles, M. \& Sánchez-Elvira-Paniagua, A. (2012). Directionality and violence expression in dating relationships of young people. Acción Psicológica, 9(1), 61-70. http://doi.org/10.5944/ap.9.1.4 37

SPDC (Social Policy and Development Centre), NUI Galway, Ipsos Mori \& ICRW (International Centre for Research on Women) (2019). Economic and Social Costs of Violence against Women in Pakistan: Summary Report April 2019. Irlanda. Galway NUI.

Stewart, W., Ricci, J., Chee, E., Hann, S. \& Morganstein, D. (2003). Cost of lost productive work time among US workers with depression. Journal of the American Medical Association, 289(23), 3135-3144. http://doi.or $\mathrm{g} / 10.1001 /$ jama.289.23.3135 
Straus, M., Hamby, S., Boney-McCoy, S. \& Sugarman, D. (1996). The revised conflict tactics scales (CTS) development and preliminary psychometric data. Journal of Family Issues, 17(3), 283-316.

Swanberg, J. E., Macke, C. \& Logan, T. K. (2006). Intimate partner violence, women, and work: Coping on the job. Violence and Victims, 21(5), 561-578.

Umana, J., Fawole, O. \& Adeoye, I. (2014). Prevalence and correlates of intimate partner violence towards female students of the university of Ibadan, Nigeria. BMC Women's Health, 14(131). http://doi.org/10.118 6/1472-6874-14-131

University of Limerick \& NUI Galway (2019). Economic and Social Costs of Violence Against Women in South Sudan: Summary Report. Irlanda, Galway: NUI Galway. https://www.ipsos.com/sites/default/files/ct /publication/documents/2019-07/economic-social-costs-violence-wo men-girls-south-sudan-2019.pdf

Valls, R., Puigvert, L., Melgar, P. \& García-Yeste, C. (2016). Breaking the silence at Spanish universities: Findings from the first study of violence against women on campuses in Spain. Violence Against Women, 22(13), 1519-1539. http://doi.org/10.1177/1077801215627511

Vänni, K., Neupane, S. \& Nygård, C. (2017). An effort to assess the relation between productivity loss costs and presenteeism at work. International Journal of Occupational Safety \& Ergonomics, 23(1), 33-43. http://doi.or $\mathrm{g} / 10.1080 / 10803548.2016 .1197578$

Vara-Horna, A. (2015). Los costos empresariales de la violencia contra las mujeres en Bolivia. Una estimación del impacto invisible para la productividad de la violencia contra las mujeres en relaciones de pareja. La Paz, Bolivia: Agencia de Cooperación Alemana GIZ.

Vara-Horna, A., Santi, I., Asencios-Gonzalez, Z. \& Lescano, G. (2017). Impacto de la violencia contra las mujeres en el desempeño laboral docente en la Región Callao - Perú. Lima, Perú: Universidad de San Martín de Porres. 
Chafloque-Céspedes et al.: Academic presenteeism and violence against women in schools...

Vázquez, F., Torres, A., Otero, P., Blanco, V. \& López, M. (2010). Prevalence and risk factors of violence against women among spanish female university students. [Prevalencia y factores de riesgo de la violencia contra la mujer en estudiantes universitarias españolas]. Psicothema, 22(2), 196-201.

Wang, J., Schmitz, N., Smailes, E., Sareen, J. \& Patten, S. (2010). Workplace characteristics, depression, and health-related presenteeism in a general population sample. Journal of Occupational and Environmental Medicine, 52(8), 836-842. http://doi.org/10.1097/JOM.0b013e3181ed3d80

Yoshida, M. \& Miki, A. (2018). Factors Related to Presenteeism in Young and Middle-aged Nurses. Sangyo Eiseigaku Zasshi (Journal of Occupational Health), 60(2), 31-40. http://doi.org/10.1539/sangyoeisei.17-019-b 